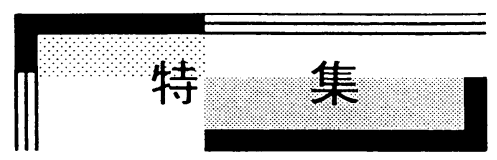

\title{
廃棄物焼却における排ガス処理技術の解説*
}

\section{Commentaries upon Exhaust Gas Treatment Technology \\ on Waste Combustion System}

\author{
篠 田高 明** \\ SHINODA Taka-aki
}

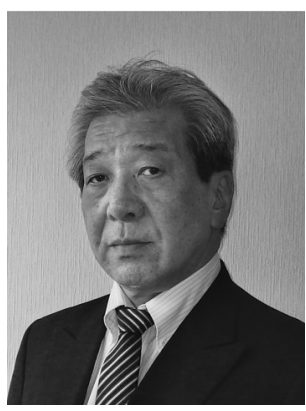

\begin{abstract}
Several types of air pollution control technologies about waste combustion system were developed on the last quarter century. If those new technologies have come into wide use, we ought to explain several new technology convincingly to customers or users. Therefore I will take a few examples of explanations about those new technologies.
\end{abstract}

Keywords: Exhaust gas treatment equipment, Air pollution control law, Fly ash, Acid gases, Dioxin

\section{1. 緒 言}

新製品を市場に投入する場合、既に実績のある 技術の組み合わせや大きな変化を伴わない改良 製品の場合には、普及一の困難は少ないと判断さ れるが、新規の技術を用いた製品を普及させよう とする時には、購入者並びに使用者が納得する説 明が必要となる。この四半世紀における廃棄物焼 却排ガスの処理では、数々の技術が開発・試行さ れ、それらの新規技術を用いた新商品が市場に投 入された。ここでは、新商品の普及に際してなさ れた新規技術の説明の例を紹介する。

\section{2. 廃棄物の焼却}

廃棄物の焼却処理で発生する副生産物 (燃え殼、 ばいじん、酸性ガス並びに有害物質等）は、他の 燃料の設備の場合と大きく異なる。一般の燃焼設 備は、ある程度調整された可燃物を燃料として使 用しているため、副生産物は燃料から予想される 範囲にある。しかしながら、廃棄物の焼却におい ては、減容と衛生処理の必要から燃燒処理される ため、必ずしも燃焼に適した燃料の性状を有して
はいない。厨芥類を代表とする雑芥、各種液状物 を含む感染性廃棄物、賞味期限切れ缶詰、脱水下 水污泥、酸性・アルカリ性廃液、使用済プラスチ ックやゴム類等の集合体で、一般の燃料とは異な るが、WDS（廃棄物データシート）やMSDS（製 品安全データシート）の情報に従い、許認可の範 囲において焼却処理される。燃焼排ガスとしては、 ある程度の範囲において想定された成分のガス となって排出される。以下においては、これら廃 棄物焼却排ガスに含まれる各種副生産物の除去 について説明する。

\section{3. ばいじん}

雑芥を主とする都市ごみを焼却すると、10\%程 度の焼却残椬が発生し、燃え残りとして炉の下部 から回収されるのが然え殸であり、炉内で浮遊し、 気流で粉砕され、燃焼ガスに随伴して集じん器等 に導かれるものがばいじんである。一般に、紙は 良く燃えるといわれるが、着火が良いことと、跡 形なく燃えることとは異なり、紙は燃焼により元 の形状より一回り小さな灰が残る。可燃分の代表

*2017.4.27 受付

** 株式会社バイオパワー勝田＝312-0002 茨城県ひたちなか市高野 1974-1

TEL: (080)8702-9632 FAX: (029) 270-3343 E-mail: sin0data@docomo.ne.jp 
と思われる紙が 100\%のセルロース $\left(\left(\mathrm{C}_{6} \mathrm{H}_{10} \mathrm{O}_{5}\right)_{\mathrm{n}}\right)$ ではない証拠であり、この灰分は紙の原料である 木質に含まれるアルカリ金属類や紙としての性 能(印刷インクの載り、硬度等)を得るために使用 された粘土質のコーティング剤等によるものと 考えられる。その他の燃焼物においても、大なり 小なり焼却残椬が発生し、燃え殼並びにばいじん になる。これらに対して、1962（昭 37）年に、「ば い煙の排出等に関する法律」が制定され、1968 （昭 43）年に「大気污染防止法」に継承された。 これらの法律により、炉の用途、規模により、ば いじん排出基準值が定められた。廃棄物焼却炉の 場合、集じん性能の高いろ過式集じん器において 捕集されるばいじんは、粒径 $0.1 \sim 200 \mu \mathrm{m}$ の紛体 で構成されており、平均粒径は 15～20 $\mu \mathrm{m}$ を中 央值としている。一般的な廃棄物焼却排ガス $1 \mathrm{~m}^{3} \mathrm{~N}$ 中には約 $5 \mathrm{~g}$ のばいじんが含まれているが、 ろ過式集じん器を通過した処理排ガスのばいじ んが $1 \mathrm{~m}^{3} \mathrm{~N}$ 中に $10 \mathrm{mg}$ 以下まで低減されているこ とより、回収されたばいじん量は発生ばいじん量 の 99.8\%以上となり、想定する回収ばいじんの平 均粒径並びに粒径分布等は概㪄正しいと思われ る。

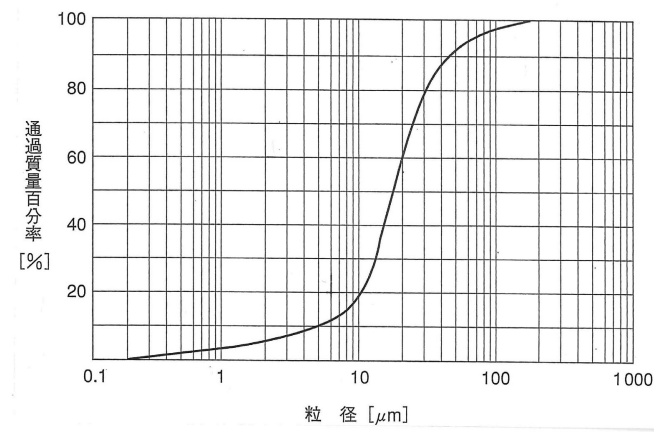

Fig. 1 Granularity diameter distribution of fly ash [1].

\section{1 燃焼ガスからのばいじんの除去（集じん）}

燃焼排ガス中のばいじんを除去する設備とし て、時代並びに地域等の要求を反映した排出基準 とその基準に対して適合可能な技術水準等によ り各種の集じん器が開発・適用された。当初は、 慣性衝突や遠心力を使用する集じん器であった が、次に静電気を使用する電気集じん器になり、 廃棄物焼却炉からのダイオキシン類の発生抑制 が求められる頃になって、急速にろ過式集じん器 が普及した。電気集じん器は、燃焼排ガス中に浮
遊するばいじんに $50 \mathrm{kV}$ 以上の高電圧を印荷して 静電気を帯電させることでクーロン力によりば いじんを集める方式であり、処理温度域も自由に 設定可能で通気抵抗も少ない設備として一世を 風靡したが、特性として比較的小さな粒子(サブ ミクロン（1 $\mu \mathrm{m}$ 未満）粒子）に対しての荷電が なされ難い傾向があるため、集じん性能に限界が あった。廃棄物焼却炉におけるろ過式集じん器は、 1983（昭 58）年頃から使用されていたが、高温 ガスにおける焼損の可能性（ろ布の耐熱 $260^{\circ} \mathrm{C}$ 程 度）から一般的には使用が控えられていた。1997 (平9)年に大気污染防止法の一部改正がなされ、 ダイオキシン類のデノボ合成 (燃焼ガス中の残留 ベンゼン等有機物と塩化水素が塩化金属類を含 有するダス卜等を触媒として $250 \sim 400^{\circ} \mathrm{C}$ の温度 域でダイオキシン類を合成する)の懸念があった 排ガス処理温度領域から、より低い温度域への冷 却が必要として、ダイオキシン類抑制のためのガ イドラインに沿った焼却施設の構造基準が制定 され、燃焼排ガスの温度を $200^{\circ} \mathrm{C}$ 以下まで泠却て きる装置の設置と運転管理として維持管理基準 が定められ、集じん器入口の燃焼排ガス温度を $200^{\circ} \mathrm{C}$ 以下にすることが示され、ろ過式集じん器 が急激に普及することになった。ろ過式集じん器 は、ガラス繊維、PTFE（ポリテトラフルオロエ チレン)、及びその他の耐熱繊維で織られた筒状 成形品をろ過材として吊るし、燃焼排ガスを $1 \mathrm{~m} / \mathrm{min}$ 以下の流速で、全量ろ過する集じん装置 である。ろ布表面に堆積したばいじんは、定期的 に外部からの新鮮な空気によりろ布に圧力をか けることによる変形で脱じんされ、集じんダスト として回収される。新品のろ布は材質並びに織り 方の違いに関わらず $60 \sim 100 \mu \mathrm{m}$ 程度の空隙があ る。Photo 1 にガラス織布の顕微鏡写真を示す。 縦系と横系の交差部分には空隙が存在している ことがわかる。また、PTFE の場合はフェルトの ろ布であり、各繊維間に空隙が存在する。Fig. 1 に示すように、ばいじんは平均粒径が 15〜20 $\mu \mathrm{m}$ であり、細かい粒子径は $0.1 \mu \mathrm{m}$ 程度であるため、 ろ布の表面において何らかの加工を行わない限 り、ばいじんの大半がろ布の空隙を通過する可能 性が極めて大きい。よって、ろ過式集じん器を初 めて使用する場合には、前もってろ布の目詰を実 施する必要がある。繊維の空隙である目を詰める 方法としは、粒径 15～20 $\mu \mathrm{m}$ で燃焼ガス中の酸 
性成分との反応がない鱗片状無機質材（目詰剂） の使用が好ましく、冷間状態において、ろ過式集 じん器に目詰剤を吹込みながら集じんするのと 同様の方式で通気し、ろ布の空隙に目詰剤で石坦 を積み上げる要領で塞ぐ。目詰により形成される 空隙は $4 \mu \mathrm{m}$ 以下となり、この操作をプレコート という。プレコートが終了すると実ガスによる使 用となるが、使用の最初はプレコート層の形成が 十分な強度となるまでは脱じんせずに使用し、ろ 過圧損が $2 \mathrm{kPa}$ となった時点で通常の脱じんを開 始する。通常のろ過圧損は $0.8 \sim 1.2 \mathrm{kPa}$ である。 プレコート層が形成されると、 $0.1 \mu \mathrm{m}$ の粒径の ばいじんも捕集される。プレコート層は一次付着 層のため、容易には剥離せず、万布の全量取替ま で、再プレコートの必要はない。

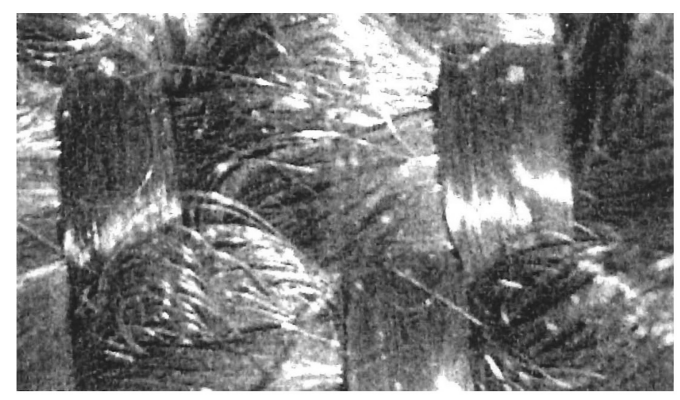

Photo 1 Magnification of Filter Surface.

\section{2 万過式集じん器の使用済みろ布の性能試験} ろ過式集じん器は、常時燃焼排ガスを全量ろ過 しているため、稼働中におけるろ過状況の観察 (集じん性能の推移、ろ過圧損の維持、集じんダ ス卜の性状等) 並びに停止に際しての定期的なる 布の抜き取り試験検査が必要になる。ろ過式集じ ん器における使用済みろ布の性能を判断する基 準として、「集じん用ろ布の試験方法一ろ布の耐 久性測定用サンプリングの方法及び試験方法」は JIS Z 8910:2007 に、「集じん用万布の試験方法 第 1 部 集じん性能」はJIS Z 8909-1:2005に、「集じ 几用万布の試験方法 第 2 部 耐久性試験方法」は JIS Z 8909-2:2008に、「集じん用万布の試験方法 第 3 部 耐熱性試験方法」はJIS Z 8909-3:2008に 規定されている。以上の JIS 規格の内、ISO 規格 化は、JIS Z 8909-1:2005 が ISO 11057:2011に、JIS Z 8909-2:2008 と JIS Z 8909-3:2008 が ISO 16891:2016 である。ISO 規格の JIS 規格化は多く
あるが、JIS 規格の ISO 規格化の例は珍しい。他 の集じんろ布の試験方法としては、Photo 2 に示 寸使用済みろ布の断面写真による目視判定があ る。堆積ダストがろ布の内部もしくは裏面まで通 過していないかを確認寸る。

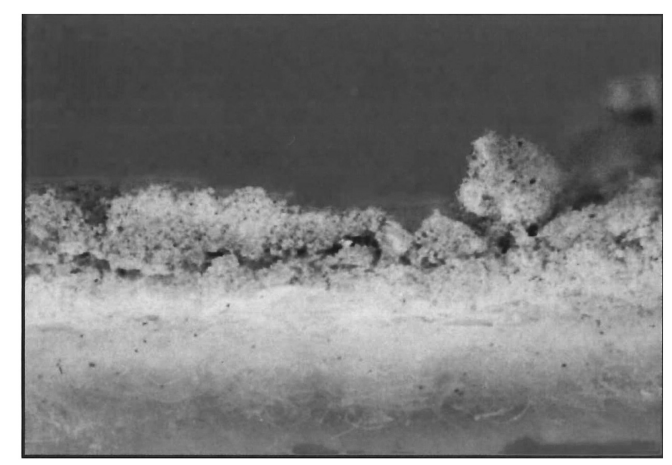

Photo 2 Magnification of Filter Cross Section.

\section{4. 燃焼ガスからの酸性成分の除去}

硫黄成分 $(\mathrm{S})$ を含む石炭や重油を燃料とする燃 焼設備においては燃焼により硫黄酸化物 $\left(\mathrm{SO}_{2}\right)$ が 生成される。この酸性雨の原因となる硫黄酸化物 を大気に放出するのを防止するための除去方式 が脱硫（硫黄酸化物の中和固定除去）である。廃 棄物の燃焼の場合では、塩素成分 $(\mathrm{Cl})$ を含む塩化 ビニルや厨芥として食塩 $(\mathrm{NaCl})$ も焼却物に含ま れるため、燃焼により硫黄酸化物以外に塩化水素 $(\mathrm{HCl})$ も発生する。この塩化水素を除去すること を脱塩と呼ぶ。また、焼却物にアンモニア基 $\left(-\mathrm{NH}_{2}\right)$ を含むたんぱく質や尿素樹脂等が含まれ る場合には、窒素酸化物(NO: Fuel NOx)が発生し、 この窒素酸化物を除去する処理を脱硝と呼ぶ。窒 素酸化物の生成には、炉内での異常高温燃焼にお いても空気中の窒素分 $\left(\mathrm{N}_{2}\right)$ の酸化により窒素酸 化物(NO：Thermal NOx)が発生する場合がある。

\section{1 石炭や重油燃焼炉での硫黄酸化物の除去}

石炭や重油の燃焼炉における脱硫方法の一つ に、炉内に炭酸カルシウム (石灰石 : $\mathrm{CaCO}_{3}$ ) を 投入して混焼し、燃料から硫黄酸化物が発生した 時に、加熱により二酸化炭素が抜けてできた酸化 カルシウム (生石灰 : $\mathrm{CaO}$ ) と反応させ、硫酸力 ルシウム（石膏 : $\mathrm{CaSO}_{4}$ ）の燃え殼として回収す る方式 (炉内脱硫法) があり、二つ目として、炉 で発生した硫黄酸化物を含む燃焼排ガスに粉末 消石灰 $(\mathrm{Ca}(\mathrm{OH}) 2)$ を噴霧し、硫酸カルシウムのば 
いじんとして集じん器で回収する方式 (乾式脱硫 法）がある。三つ目として、炉で発生した硫黄酸 化物を含む燃焼排ガスを洗煙 (中和水で燃焼排ガ スを洗浄）し、硫酸水となった洗浄水を水酸化ナ トリウム $(\mathrm{NaOH})$ で中和して硫酸ナトリウム $\left(\mathrm{Na}_{2} \mathrm{SO}_{4}\right.$ ：可溶性）塩水、もしくは消石灰で中和 して硫酸カルシウム (難溶性) の沈殿物として回 収する方式 (湿式脱硫法) がある。これらの脱硫 方法の内、炉内脱硫法は炭酸カルシウムが炉内で 焼かれることにより酸化カルシウムになる過程 で表面に $0.2 \mu \mathrm{m}$ 幅の亀裂が多数発生するものの、 全体としては細粒化せず塊状体のため、硫黄酸化 物との接触確率が低いことより、除去効率も低く なる。また、乾式脱硫法は粉末消石灰の表面に難 溶性の硫酸カルシウム層が薄く形成されるため、 内部に未反応の消石灰が残留し、吹込み消石灰量 に比して反応効率が高くない。湿式脱硫法は古く からある技術であるが、燃焼排ガスを中和水で直 接洗浄するため、含有する硫黄酸化物が硫酸とし て洗浄水に完全に溶解した後、中和寸るため、反 応効率が極めて高い。以上より、石炭や重油を燃 料とする製鋼業や火力発電所等の燃焼炉におい ては現在も、電気集じん器と湿式脱硫法を組み合 わせた燃焼排ガス処理方式が多い。

\section{2 廃棄物焼却炉での酸性成分の除去}

廃棄物燃焼における酸性ガスの処理において も、当初は石炭や重油の燃焼炉で得られた知見を 基にした処理方式が適用された。電気集じん器が 全盛の頃は、酸性ガスの処理温度も比較的に高く、 湿式脱硫法が主流であり、硫黄酸化物だけでなく 塩化水素も高効率で除去できるため、大都市圈で 多用された。1977（昭 52）年頃から使用されて きた乾式脱硫法は、万過式集じん器の普及による 複合効果 (粉末消石灰と硫黄酸化物との反応時間 確保と低温度反応）により、反応効率の向上が期 待されることで、湿式脱硫法に比して設備費と運 転費が安価な乾式脱硫法の開発が進められた。粉 末消石灰と硫黄酸化物のガス単体の実験では、消 石灰粒子の表面に硫酸カルシウム被膜の形成で 温度並びに時間による反応効率の変化が見られ なかったので、消石灰の比表面積を増加させる開 発が行われ、微粒子化と表面の凹凸増加が試みら れ、高反応消石灰の開発となった。微粒子化は、 ろ過式集じん器のろ布の目詰まりを促進するた め、普及せず、粒径は維持したまま、比表面積だ
けを増大した高反応消石灰が普及した。廃棄物焼 却設備では、燃焼排ガスに硫黄酸化物だけでなく 塩化水素を多量（硫黄酸化物の 10 倍程度）に含 むと共に、水分も共存するため、単体ガスによる 個別実験とは異なる結果が得られた。燃焼排ガス に吹き込まれた粉末消石灰は大気温度に冷却さ れているため、表面では燃焼排ガス中の水分が結 露すると共に、多量にある塩化水素と高効率で反 応する。反応によって生成された塩化カルシウム

$\left(\mathrm{CaCl}_{2}\right)$ は潮解性を有するため、さらに燃焼ガ ス中の水分を吸収し、この水分に硫黄酸化物が溶 解して硫酸が生成されると共に、消石灰内部に浸 透する。消石灰の内部では、一部の塩化カルシウ ムを分解し、塩化水素を放出して硫酸カルシウム に置換される。これら一連の反応は、燃焼ガス中 に塩化水素と水分が多量にあることを前提とし ており、低温程反応効率が高い。これらの成果に より、廃棄物焼却炉においては乾式法が普及する のに至った。ただし、集じん器で回収されたダス トには多量の塩化カルシウムを含有するため、潮 解性を有し、ろ布の吸湿・固化及び搬送機器等の 腐食に留意する必要がある。粉末消石灰の代替と して、炭酸水素ナトリウム $\left(\mathrm{NaHCO}_{3}\right)$ を使用直前 に粉砕して噴霧する方式も開発されている。

\section{3 廃棄物焼却炉での窒素酸化物の除去}

廃棄物中のタンパク質や尿素樹脂等の燃焼並 びに燃焼用空気の局所高温により発生する窒素 酸化物も燃焼により発生する有害副生産物であ り、オキシダントの原因であるため、その時代及 び地域により設定された規制值以下に抑制しな ければならない。燃焼用空気からの窒素酸化物に 対しては、燃焼炉内の温度管理と酸素濃度管理が 有効であるが、燃料に含有されたアンモニア基の 燃焼により発生する窒素酸化物は完全燃焼を目 指す廃棄物焼却では不可避である。生成された窒 素酸化物の除去方法としては、炉内の 750〜 $1,000^{\circ} \mathrm{C}$ の然焼域に発生する窒素酸化物の量と同 当量（100\%反応した場合の量）以下のアンモニ ア水又は尿素水を噴霧し、還元雾囲気を形成して 窒素酸化物を窒素ガス $\left(\mathrm{N}_{2}\right)$ にするのが無触媒脱 硝法であり、発生窒素酸化物濃度の $30 \%$ 程度の 削減を目標とする場合に用いる。噴霧するアンモ ニア剂の大半が未反応のまま炉から放出され、燃 焼ガス中の塩化水素と反応して塩化アンモニウ ム（ $\mathrm{NH}_{4} \mathrm{Cl} ）$ を生成し、紫煙の原因となるため、 
$30 \%$ 以上の効率を求めることは危険である。設備 が簡便なため、規制の低い地域で普及している。 窒素酸化物のさらなる削減を求める方法として は、五酸化二バナジウム $\left(\mathrm{V}_{2} \mathrm{O}_{5}\right)$ 等を触媒とし、 アンモニアガスを還元剤とする触媒脱硝法があ る。この反応を利用するには触媒が活性を持つ 200 $400^{\circ} \mathrm{C}$ の温度域と残留酸素が必要となる。反 応は良好で、削減しょうとする窒素酸化物量と同 当量のアンモニア還元剤の使用で達成される。触 媒は二酸化チタン $\left(\mathrm{TiO}_{2}\right)$ や酸化アルミニウム

$\left(\mathrm{Al}_{2} \mathrm{O}_{3}\right)$ を担持体として触媒成分を担持した八 ニカム若しくはペレットで然焼排ガスを全量通 過させる。触媒の劣化としては、硫黄酸化物の酸 化により生成する無水硫酸 $\left(\mathrm{SO}_{3}\right)$ と還元剤のア ンモニアとの反応物の加水分解物である硫酸水 素アンモニウム（酸性硫安 : $\mathrm{NH}_{4} \mathrm{HSO}_{4}$ ) の付着劣 化等がある。この被毒は硫黄酸化物濃度の対数的 累積となるため、触媒の延命化には硫黄酸化物濃 度を抑えることが重要である。その他の劣化原因 としては、ばいじんの堆積による閉塞やアルカリ 金属類との置換劣化があるが、十分な集じんを行 い、酸性ガスの除去後、活性に必要な温度域まで の昇温を行えば性能は安定している。無触媒法に 比して設備費が高額となるため、規制の厳しい地 域で設置されている。

\section{5. その他の有害成分 (ダイオキシン類)}

1999 (平 11) 年に施行された「ダイオキシン類 対策特別措置法」により、製鋼用電気炉並びに廃 衰物焼却炉等に対して、施設から発生する排ガス 中のダイオキシン類やそれらの設備に付帯する 集じん器で回収されたばいじんに含有されるダ イオキシン類に対する規制が始まった。燃焼炉内 においてダイオキシン類を発生させないために は、燃焼に必要な燃焼用空気の存在の下、十分な 混合擋挥がなされ、 $800^{\circ} \mathrm{C}$ 以上 $\left(850^{\circ} \mathrm{C}\right.$ 以上が望ま しい)の温度での燃焼を 2 秒以上継続して行う必 要がある。

\section{1 燃焼排ガス中のダイオキシン類の除去}

ダイオキシン類は発生させないことが肝要で あるが、異常燃焼等で、燃焼排ガス中に規制值を 上回るダイオキシン類を含む場合には、大気に放 出する前に除去しなければならない。燃焼排ガス 中のダイオキシン類の除去方法としては、活性炭 による吸着除去法と酸化触媒による分解法があ
る。また、活性炭による吸着除去法には粉末活性 炭の吹込み法と活性炭充填塔による吸着法があ る。活性炭による吸着法は、ダイオキシン分子 (ダ イオキシン類は存在が希薄 (数 $10^{-9} \mathrm{~g} / \mathrm{m}^{3}$ ) なため、 融点以下でもガス状の固体分子) の大きさ $(1.4 \mathrm{~nm}$ $\times 0.7 \mathrm{~nm} \times 0.35 \mathrm{~nm}$ 程度）に注目し、その最大長 $1.4 \mathrm{~nm}$ の 1.7 倍程度の 2 $5 \mathrm{~nm}$ の平均細孔直径の 活性炭が好ましく、低温ほど効率が高い。吹き込 み法は乾式脱硫法と同様にろ過式集じん器の上 流に吹込み、ろ過式集じん器でダストとして回収 する。活性炭吸着塔は、充填された活性炭がばい じんで目詰まりしないように集じん器の下流に 設置する。構造上、活性炭吹き込夕法に比して高 価になる。これらの活性炭は、水銀も吸着する。 触媒法は、脱硝用触媒が流用でき、触媒の酸化性 能で容易に分解する。濃度が薄いため、酸性ガス の値に変化はない。

\section{6. 最後に}

廃棄物燃焼における排ガスの処理の代表的な 技術を紹介した。何かの参考になれば幸いである。

\section{参考文献}

[1] The Japan Waste Research Foundation ed., Fly Ash Treatment Guidance on Specially Controlled Municipal Waste, Series III (in Japanese), 150-167, 202-219, The Chemical Daily Co.,Ltd., Tokyo, (1993).

[2] Tejima H., Nakagawa I., Shinoda T. and Maeda I., PCDDs/PCDFs Reduction by Good Combustion Technology and Fabric Filter with/without Activated Carbon Injection, Chemosphere, Vol.32, (1), 169-175, (1996)

[3] Takuma Environmental Research Association ed., Refuse \& Burning Technology (in Japanese), 150-167 \& 202-219, Ohmsha Ltd., Tokyo, (1998).

[4] Shinoda T., Control Technology to Remove PCDDs/PCDFs in Refuse Incineration Plant (Activated Carbon Powder Injection Method), Japanese Journal of Multiphase Flow, Vol.12, (1), 28-34, (1998).

[5] Takuma Environmental Research Association ed., Air Pollution Control Technology (in Japanese), 40-89, Ohmsha Ltd., Tokyo, (2000).

[6] Shinoda T., New Trends and Issues in Air Pollution Control Technologies for Municipal Solid Waste Incineration Plant, Journal of Chemical Engineering of Japan, Vol.66, (9), 519-521, (2002). 